\title{
ТЕХНОЛОГИЯ ВЕБ-КВЕСТА: НОВЫЙ ВЗГЛЯД НА ОБУЧЕНИЕ АКЦЕНТОЛОГИЧЕСКИМ НОРМАМ УЧАЩИХСЯ СРЕДНИХ ШКОЛ
}

\section{Иванищева О.Н.}

ФГБОУ ВО «Мурманский арктический государственный университет», г. Мурманск, Российская Федерация

В статье рассматривается отличие веб-квеста от проблемного обучения, представлен вариант проведения веб-квеста при обучении акцентологическим нормам (на примере Экспертный-экспЕртный)

Ключевые слова: веб-квест; инновационные технологии обучения русскому языку; акиентологические нормы.

\section{WEB QUEST TECHNOLOGY: A NEW LOOK AT LEARNING STUDENTS OF SECONDARY SCHOOLS RUSSIAN ACCENTHOLOGICAL NORMS}

\section{Ivanishcheva O.N.}

Murmansk Artic State University, Murmansk, Russian Federation

The article shows the difference between a web quest and problem-based learning, presents a variant of teaching Russian accentological norms with help of web quest technology (Экспертный-экспЕртный)

Keywords: web quest; innovative technologies of teaching Russian language; Russian accentological norms.

\section{Введение}

Технология веб-квеста признается перспективной инновационной технологией при обучении русскому языку в разных образовательных средах: в средней и в высшей школе, при обучении русскому языку как родному и неродному. 
Однако исследователи и методисты по-разному понимают суть метода веб-квеста: одни воспринимают его как проблемное задание с элементами ролевой игры, другие - как веб-проект (веб-страницу), третьи - как вид проблемно-ориентированных, индивидуальных или групповых заданий с использованием Интернета, четвертые - как сценарий проектной деятельности (например: [3, с. 4]).

Цель данной статьи - выявить специфику технологии веб-квеста по сравнению с проектным обучением (выполнением совместного проекта).

Используемые методы исследования: теоретические (анализ методической литературы по теме) и эмпирические (наблюдение, анализ).

\section{Результаты исследования}

Одним из условий использования веб-квеста в любой образовательной среде является хорошее владение русским языком (см. об этом: [2]).

Веб-квест понимается как целенаправленный поиск информации. Методисты и исследователи выявляют следующую логику использования веб-квеста: определение учебной проблемы, которую надо решить, поиск информации группой учащихся в Интернете, работа учащихся с тематическими сайтами, предложенными учителем (технология веб-квеста).

В рамках проектного обучения технология обучения русскому языку основана на определенной задаче, которая решается с помощью Интернет-ресурсов. Результатов такой работы становится рассказ, создание Интернет-журнала, составление визуального образа той или иной ситуации, ролевая игра.

Технология веб-квеста, с нашей точки зрения, основана на идее постепенного перехода от одной «точки» знания к другой: поиск одного решения ведет к траектории поиска следующей задачи и ее решения. Цепочка таких задач и их решений приводит к выводам, который делает учащийся самостоятельно. Именно такой последовательности лишен метод проектного обучения. В нем проблемный 
вопрос решается путем сопоставления разных точек зрения, но последовательный переход от одной позиции к другой необязателен.

Пример урока по усвоению произносительных норм:

Тип урока - контрольный, форма урока - прохождение веб-квеста.

В начале урока (системы уроков) учитель представляет проблемное задание: определить произносительную норму, выявить ее варианты, определить условия их употребления, установить основной вариант произносительной нормы. Полезно провести входящее анкетирование, проверяющее знание учащихся до решения проблемы с помощью веб-квеста.

Известно, что произносительные нормы часто нарушаются в речевой практике (бытовые сферы, СМИ), поэтому важно научить учащихся формировать устойчивую позицию по отношению к правильному произносительному варианту. Примером такого употребления может быть слово «экспертный» с его произносительным нелитературным вариантом «экспертный».

Учащимся предлагается следующая образовательная траектория: постановка проблемы (неправильное/правильное ударение - кто так говорит? http://mnogoznay.ru/russkiy-yazyk/udarenie-v-slovah-kakpravilno/udarenie-v-slove-ekspert.html\#i-3), выявление реальной речевой практики (ped-znanie.ru/conference0428/1083.docx; www.bmstu. ru/ps/ orlov/fileman/download/...е\%\%20изд./Eco_Metrika2.pdf), решение проблемной ситуации (переход от одного звена (реальная речевая практика) к другому (мнение экспертов (орфоэпические словари)).

\section{Обсуждение}

Новым в такой технологии обучения акцентологическим нормам является то, что учащиеся видят реальную речевую практику (как кто говорит). Такая позиция определяет сознательность в обучении русскому языку, не навязывает норму, которая определена специалистами, а выявляется в процессе самостоятельного поиска информации о причинах такого ударения. Неправильные варианты учащиеся постоянно встречают в жизни, а в школе им «навязывают» правильный вариант. Такое механическое заучивание не пред- 
упреждает ошибок, потому что неотработанная норма вступает в противоречие с реальной речевой практикой, которую учащиеся слышат подчас чаще в неправильном варианте.

\section{Заключение}

Веб-квест технологии в обучении русскому языку в литературе не всегда отличаются от заданий проблемного и проектного характера. При таком подходе забывается исконное значение термина «квест», подразумевающий жанр игр, в котором игроку требуется решать головоломки и умственные задачи для достижения конечной цели $[1$, c. 36]. При обучении акцентологическим нормам современного русского языка важно учитывать реальную речевую практику, которая подчас вступает в противоречие с акцентологическими нормами и является серьезным препятствием при обучении учащихся правильному произношению. Веб-квест, который предложит реальные случаи правильного и неправильного употребления слова, даст учащемуся возможность сознательного восприятия норм русского литературного языка, а значит, более прочного их усвоения.

\section{Список литературы}

1. Акинин И.А. Веб-квест как форма проявления синергетического подхода в классическом образовательном процессе // Общество: философия, история, культура. 2017. № 7. С. 35-38.

2. Вавулина А.В., Николенко Е.Ю. Методические особенности использования технологии веб-квест при обучении РКИ на разных уровнях // Stephanos. 2017. № 5 (25). С. 81-91.

3. Шульгина Е.М. Методика формирования коммуникативной компетентности студентов посредством технологии веб-квест (профиль «Рекреационная география и туризм», английский язык) : автореф. дис. ... канд. пед. наук. Тамбов, 2014. 23 с.

\section{References}

1. Akinin I.A. Veb-kvest kak forma proyavleniya sinergeticheskogo podhoda $\mathrm{v}$ klassicheskom obrazovatel'nom processe [Web quest as a form of 
manifestation of a synergistic approach in the classical educational process]. Obshchestvo: filosofiya, istoriya, kul'tura, 2017, № 7, pp. 35-38.

2. Vavulina A.V., Nikolenko E.Yu. Metodicheskie osobennosti ispol'zovaniya tekhnologii veb-kvest pri obuchenii RKI na raznyh urovnyah [Methodical features of using the technology of a web quest when teaching RCTs at different levels]. Stephanos, 2017, № 5 (25), pp. 81-91.

3. Shul'gina E.M. Metodika formirovaniya kommunikativnoj kompetentnosti studentov posredstvom tekhnologii veb-kvest (profil' "Rekreacionnaya geografiya i turizm», anglijskij yazyk). Avtoref. cand. diss. [Methods of forming the communicative competence of students through the technology of the web quest (profile "Recreational Geography and Tourism", English). Abstr. cand. diss.]. Tambov, 2014. 23 p. 